\title{
Unusual electrocardiographic presentation of conduction disturbances from acute use of chloroquine: rare case report
}

\author{
Nietypowy elektrokardiograficzny zapis zaburzeń przewodzenia \\ po zastosowaniu chlorochiny - opis rzadkiego przypadku
}

\author{
Santosh Kumar Sinha, Mukesh Jitendra Jha, Nasar Afdaali, \\ Ramesh Thakur, Chandra Mohan Varma \\ Department of Cardiology, LPS Institute of Cardiology, G.S.V.M. Medical College, Kanpur, India
}

\begin{abstract}
23-year-old man presented with Stokes-Adams attacks due to sinus node dysfunction. He was being treated for malaria with chloroquine for the last two days. Temporary pacemaker was implanted. Subsequently he developed all spectrum of atrioventricular block following recovery of sinus node dysfunction which also recovered on the fifteenth day and was discharged. Cardiac damage, such as cardiomyopathy and conduction system disturbances, is regarded as uncommon consequences of acute chloroquines's toxicity. Here we present a case in which chloroquine used as acute therapy for malaria resulted in conduction disorder beginning from sinus node dysfunction to Mobitz I atrioventricular block to complete heart block with recovery to normal sinus rhythm in single patient.
\end{abstract}

Key words: chloroquine, complete heart block, malaria, Mobitz I atrioventricular block, sinus node dysfunction

Folia Cardiologica 2017; 12, 3: 271-273

\section{Introduction}

Chloroquine as a derivative of 4-aminoquinoline has been widely used as an antimalarial agent and for rheumatological treatment, but potential severe side effects require careful follow-up. Cardiac damage is not a common consequence. Owing to its narrow therapeutic index the drug is relatively toxic, especially in the case of an overdose, an acute intoxication or chronic uses for rheumatological disorders. Conduction disorders in usual doses are extremely rare and such presentation in single patient is even rarer.

\section{Case report}

We report the case of a 23-year-old man with $P$. vivax malaria, diagnosed three days ago. Subsequently treatment with chloroquine in usual dose: $600 \mathrm{mg}$. was initiated and then $300 \mathrm{mg} 6,24$ and 48 hours after the first dose. He was admitted with syncope. No other previous cardiovascular symptoms were reported. There was no family history of cardiac disease. His physical examination was normal on admission except for the pulse rate of $37 \mathrm{bpm}$. The electrocardiogram showed sinus node dysfunction with left bundle-branch block QRS morphology (Fig. 1). Temporary pacemaker implantation was done under aseptic condition after proper consent. Routine blood investigations, electrolytes (calcium, phosphorus, magnesium, sodium, and potassium) and cardiac biomarkers (myoglobin, CPK-MB and troponins) were normal. Others parameters such as serum bilirubin, AST and ALT, blood urea and serum creatinine were within normal range. The echocardiogram revealed normal cardiac function and cavity dimensions

Address for correspondence: Santosh Kumar Sinha MD, FAESC, Asst. Professor, Department of Cardiology, LPS Institute of Cardiology, G.S.V.M. Medical College, G.T. Road, Kanpur, Uttar Pradesh 208002, India, e-mail: fionasan@rediffmail.com 


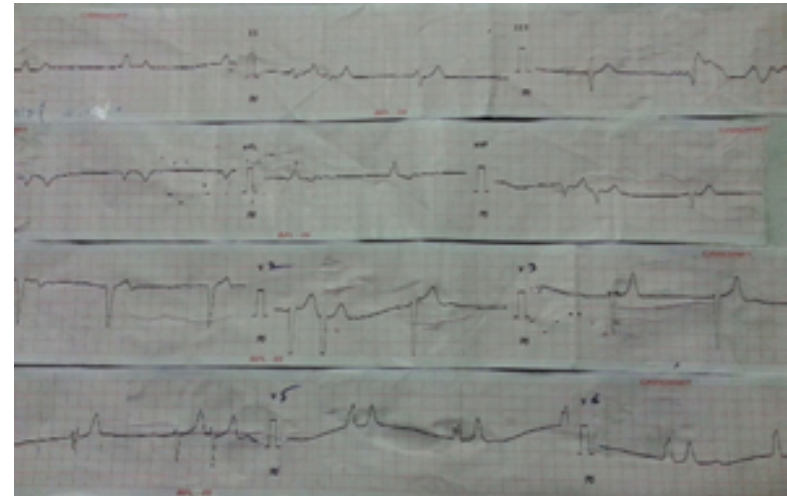

Figure 1. Sinus node dysfunction with left bundle-branch block QRS morphology

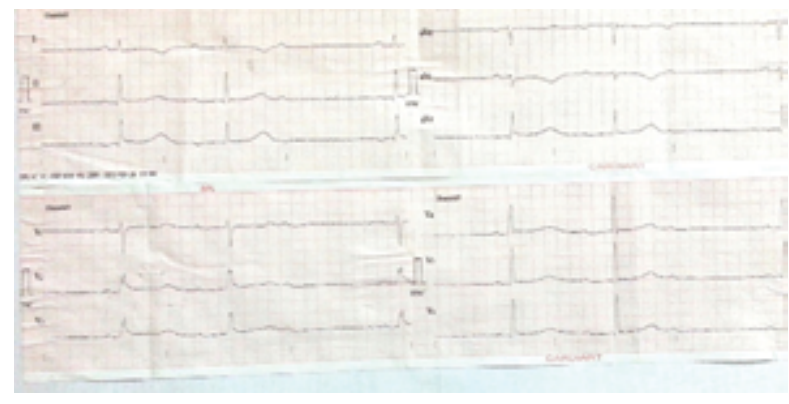

Figure 2. Complete heart block with ventricular escape of 22/min

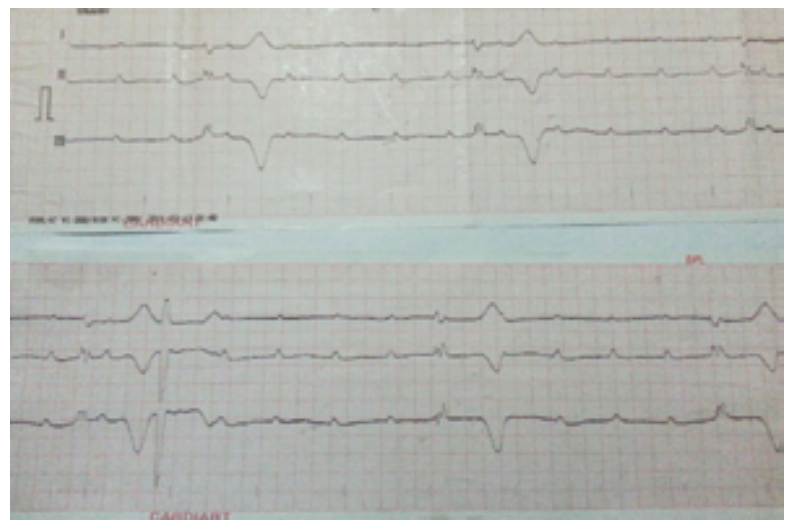

Figure 3. Mobitz type I atrioventricular block

and thus congenital heart diseases were ruled out. Holter monitoring was also done to rule out any tachyarrhythmias in form of NSVT or VT. Sinus node dysfunction recovered on fourth day. He subsequently developed Mobitz type I atrioventricular block (Fig. 2) and complete heart block on the seventh day (Fig. 3) which finally recovered to normal sinus rhythm on the fifteenth day. Coronary angiography was normal. Patient was discharged in stable condition.

\section{Discussion}

Chloroquine is an antimalarial drug of 4-aminoquinolines group. Chloroquine is the drug of choice for clinical cure and suppressive prophylaxis of all types of malaria, except that caused by resistant P-falciparum. Chloroquine exerts its toxicity by quinidine-like mechanisms. It is a profound negative inotrope and a vasodilator. It also slows intraventricular conduction. Oral chloroquine is rapidly and almost completely absorbed, resulting in transiently high blood concentrations early in the distribution phase that are potentially cardiotoxic [1]. Chloroquine, like amiodarone (class III anti-arrhythmic) is inhibitor of phospholipase activity and induces cytoplasmic inclusion body formation. Chloroquine is accumulated in lysosomes, directly inhibiting enzymatic activity, increasing lysosomal pH and causing protein inactivity $[2,3]$. Because of its properties, it may cause arrhythmias [2, 4]. Major arrhythmias basically caused by chronic use of chloroquine have been attributed to significant reduction in the cardiac ascent rate, increases in the potential length duration, and Purkinje fibbers refractory period $[3,5]$. The usual electrocardiographic alteration is fascicular block, which can lead to advanced types of atrioventricular block causing syncope [6]. Acute rhythm disturbances with usual dose is extremely rare. The diagnosis of chloroquine cardio toxicity is determined by endomyocardial biopsy. Holter study ruling out any tachyarrhythmia's also negated any drug induced myocarditis. Also his cardiac biomarkers were negative and LV functions were normal, also supported our case. Although histologic studies were not performed in our patient, the clinical evidence of toxicity, absence of underlying heart disease, fairly young age of the patient and the duration of use pointed to chloroquine toxicity. Sinus node dysfunction alone in acute use of chloroquine is very rare though has been reported as chloroquine-induced cardiomyopathy involving the heart conduction system [7]. Our case is unique as sinus node dysfunction without cardiomyopathy in acute setting is rare. Also Mobitz-I AV block progressing to complete heart block and recovering to normal sinus rhythm is too unusual. As normal sinus rhythm was restored, patient was discharged without pacemaker.

\section{Conflict of interest(s)}

None. 


\section{Streszczenie}

Mężczyzna w wieku 23 lat zgłosił się do lekarza z powodu napadów Morgagniego-Adamsa-Stokesa będących następstwem dysfunkcji węzła zatokowego. Przez ostatnie 2 dni stosował chlorochinę w ramach leczenia przeciwmalarycznego. Tymczasowo wszczepiono mu stymulator serca. Po ustąpieniu zaburzeń węzła zatokowego u chorego rozwinął się pełny blok przedsionkowo-komorowy, który również ustąpił po 15 dniach i chorego wypisano do domu. Uszkodzenie serca w postaci kardiomiopatii lub zaburzeń przewodzenia jest rzadkim następstwem ostrego toksycznego działania chlorochiny. W artykule przedstawiono przypadek pacjenta, u którego po zastosowaniu chlorochiny w leczeniu ostrego napadu malarii wystąpiło całe spektrum zaburzeń przewodzenia - od dysfunkcji węzła zatokowego, przez blok przedsionkowo-komorowy typu Mobitz I, do całkowitego bloku przedsionkowo komorowego - zakończonych przywróceniem prawidłowego rytmu zatokowego.

Słowa kluczowe: chlorochina, całkowity blok serca, malaria, blok przedsionkowo-komorowy typu Mobitz I, dysfunkcja węzła zatokowego

Folia Cardiologica 2017; 12, 3: 271-273

\section{References}

1. Don Michael TA, Aiwazzadeh S. The effects of acute chloroquine poisoning with special reference to the heart. Am Heart J. 1970; 79(6): 831-842, indexed in Pubmed: 5419357.

2. Harris L, Downar E, Shaikh NA, et al. Antiarrhythmic potential of chloroquine: new use for an old drug. Can J Cardiol. 1988; 4(6): 295-300, indexed in Pubmed: 2460205.

3. Ratliff NB, Estes ML, Myles JL, et al. Diagnosis of chloroquine cardiomyopathy by endomyocardial biopsy. N Engl J Med. 1987; 316(4): 191-193, doi: 10.1056/NEJM198701223160405, indexed in Pubmed: 3796692.

4. Siqueira-Batista R, Ramos Júnior AN, Pessanha BS, et al. Chloroquine and cardiac arrhythmia: case report. East Afr Med J. 1998; 75(2): 117-119, indexed in Pubmed: 9640837.
5. Seshadri MS, John L, Varkey K, et al. Ventricular tachycardia in a patient on dehydroemetine and chloroquine for amoebic liver abscess. Med J Aust. 1979; 1(9): 406-407, indexed in Pubmed: 38383.

6. Verny $\mathrm{C}$, de Gennes $\mathrm{C}$, Sébastien P, et al. [Heart conduction disorders in long-term treatment with chloroquine. Two new cases]. Presse Med. 1992; 21(17): 800-804, indexed in Pubmed: 1535141.

7. Lee JH, Chung WB, Kang JuH, et al. A case of chloroquine-induced cardiomyopathy that presented as sick sinus syndrome. Korean Circ J. 2010; 40(11): 604-608, doi: 10.4070/kcj.2010.40.11.604, indexed in Pubmed: 21217940. 